\title{
KEPASTIAN HUKUM TERHADAP PENGASUHAN ANAK MUMAYIZ PASCA PERCERAIAN
}

\author{
Kajian Putusan Nomor 175/PDT.G/2011/MS-BNA
}

\section{LEGAL CERTAINTY FOR MUMAYIZ MINORS IN POST-DIVORCE CUSTODY}

\author{
An Analysis of Court Decision Number 175/PDT.G/2011/MS-BNA
}

\author{
Mansari \\ Pusat Kajian Pendidikan dan Masyarakat Aceh \\ J1. Prada Utama No. 113, Gampong Pineung Banda Aceh 24415 \\ E-mail: mansari_kaisar@ymail.com
}

\section{Reza Maulana}

Alumni Fakultas Syariah dan Hukum UIN Ar-Raniry Banda Aceh

Gampong Lampisang, Aceh Besar, Jl. Banda Aceh, Meulaboh, Banda Aceh 23232

E-mail: rezamoulana@gmail.com

Naskah diterima: 13 Maret 2017; revisi: 17 November 2017; disetujui 27 Maret 2018

http://dx.doi.org/10.29123/jy.v11i1.139

\begin{abstract}
ABSTRAK
Anak yang telah mumayiz diberikan kebebasan memilih tinggal bersama ibu atau ayahnya. Kesempatan untuk memilih harus dinyatakan secara eksplisit dalam putusan untuk menghindari konflik di kemudian hari antara kedua orang tuanya. Berbeda dalam Putusan Nomor 175/PDT.G/2011/MS-BNA yang tidak langsung menetapkan anak yang telah mumayiz diasuh oleh ibu atau ayahnya. Hal ini dikhawatirkan akan menimbulkan persoalan hukum di kemudian hari demi memperebutkan anak tersebut. Permasalahannya adalah bagaimana aspek kepastian hukum terhadap pemeliharaan anak mumayiz dalam Putusan Nomor 175/PDT.G/2011/ MS-BNA, dan bagaimana perlindungan hukum bagi anak mumayiz yang belum menentukan pilihannya? Penelitian ini termasuk penelitian empiris dan datanya
\end{abstract}

diperoleh melalui wawancara hakim dan putusan Mahkamah Syar'iyah Banda Aceh. Hasil penelitian menunjukkan bahwa Putusan Nomor 175/PDT.G/2011/ MS-BNA tidak mencerminkan kepastian hukum bagi anak yang telah mumayiz. Hal ini dikarenakan anak yang berumur 14 dan 18 tahun tidak jelas berada di bawah pengasuhan ibu atau ayahnya. Perlindungan hukum bagi anak mumayiz yang belum menentukan sikap/pilihan menjadi kewajiban bersama kedua orang tua untuk mengasuh dan memeliharanya. Jika anak sudah menentukan pilihan dan memilih ibu sebagai pengasuhnya, maka ia wajib memelihara dan mengasuhnya hingga dewasa dan ayah berkewajiban memberikan nafkah kepadanya. Sebaliknya, jika ayah menjadi pilihannya, kewajiban mengasuh, merawat, dan menafkahi menjadi kewajibannya. 
Kata kunci: kepastian hukum, pengasuhan, perceraian, anak mumayiz.

\section{ABSTRACT}

A Minor who has been mumayiz is given freedom to choose to live either with the mother or father. The decision should be explicitly stated in court decision to avoid future conflicts between the parents. In contrast, Court Decision Number 175/PDT.G/2011/MS-BNA did not in a straight line determine the status of a minor who has been mumayiz to be raised by either the mother or father. This could lead to legal dispute of fighting over the minor in the future. The question is how the legal certainty in the custody of minors with mumayyiz status in Court Decision Number 175/PDT.G/2011/MS-BNA and how the law provide protection for them who have not made their choice yet? This study is done by empirical research and the data collected through interviews of

\section{PENDAHULUAN}

\section{A. Latar Belakang}

Konsekuensi terjadinya perceraian orang tua adalah munculnya kewajiban memelihara anak-anak yang lahir dari perkawinan tersebut. Kedua orang tua wajib memelihara, melindungi, dan menjaga anaknya hingga dewasa. Kewajiban memelihara anak setelah perceraian dalam istilah fikih disebut hadanah. Syarifuddin (2014: 327) mendefinisikan hadanah sebagai pemeliharaan anak yang masih kecil setelah terjadinya putus perkawinan.

Menurut ulama fikih hadanah adalah melakukan pemeliharaan anak yang masih kecil laki-laki maupun perempuan, atau yang sudah besar tetapi belum mumayiz, menyediakan sesuatu yang menjadikan kebaikannya, menjaga sesuatu dari yang menyakiti dan merusaknya, mendidik jasmani, rohani dan akalnya, agar mampu berdiri judges and the ruling of Syar'iyah Court of Banda Aceh. The results show that the Court Decision Number 175/ PDT.G/2011/MS-BNA does not reflect legal certainty for the minors with the status of mumayiz. This is because the law does not set off that minors aged of 14 and 18 are in care of their mother or father. While the law has set for minors who have not mumayiz because of the existence of parenting to the mother has been confirmed in the verdict. Legal protection for undecided custody of mumayiz minors will be obliged to their both parents to nurture and raise. If the child has made a choice and chooses the mother as the caregiver, then she is obliged to care and nurture the child to adulthood, and the father is obliged to provide a livelihood for the child. On the other hand, if the father becomes the child's choice, the obligation to care, nurture, and provide a livelihood becomes his duty.

Keywords: legal certainty, custody, divorce, mumayiz minors.

sendiri menghadapi hidup dan memikul tanggung jawab (Ghozali, 2010: 175-176).

Kompilasi Hukum Islam mengatur tentang pemeliharaan anak pasca putusnya hubungan perkawinan orang tua dalam Pasal 105 yang menyatakan dalam hal terjadinya perceraian:

1. Pemeliharaan anak yang belum mumayiz atau belum berumur 12 tahun adalah hak ibunya;

2. Pemeliharaan anak yang sudah mumayiz diserahkan kepada anak untuk memilih di antara ayah atau ibunya sebagai pemegang hak pemeliharaannya;

3. Biaya pemeliharaan ditanggung oleh ayahnya.

Dengan demikian, anak yang belum mencapai umur 12 tahun atau belum mumayiz menjadi hak ibunya untuk mengasuh dan 
memeliharanya hingga dewasa. Setelah mumayiz anak diberikan kesempatan memilih tinggal bersama ibu maupun ayahnya. Pada usia ini seorang anak sudah dapat membedakan yang berdampak positif maupun negatif bagi dirinya. Oleh karenanya, ia dapat diberikan kebebasan memilih tinggal bersama ibu atau ayahnya. Sementara biaya pemeliharaannya tetap menjadi tanggung jawab ayahnya.

Ketentuan yang membolehkan anak memilih ini perlu diperhatikan oleh hakim dalam memutuskan perkara. Ketidakhati-hatian hakim tanpa mempertimbangkan kebolehan anak memilih akan menimbulkan persoalan hukum di kemudian hari yakni tidak adanya kepastian hukum bagi anak tersebut. Seperti Putusan Nomor 175/PDT.G/2011/MS-BNA yang menetapkan dua orang anak yang belum mumayiz berada di bawah asuhan penggugat (ibu), sedangkan dua anak lainnya yang telah berumur 14 dan 18 tahun tidak dijelaskan berada di bawah asuhan penggugat maupun tergugat. Anak yang berumur 18 tahun merupakan anak yang lahir dari perkawinan tergugat dengan kakak kandung penggugat (anak tiri antara penggugat dan tergugat).

Penggugat meminta kepada hakim memutuskan empat orang anak berada di bawah pengasuhannya. Poin ketiga petitum berbunyi: "Menetapkan penggugat sebagai pengasuh terhadap empat orang anak yang namanya tersebut di atas." Artinya penggugat menginginkan empat orang tersebut berada di bawah pengasuhannya, baik anak yang lahir antara penggugat dengan tergugat maupun anak yang lahir dari perkawinan antara kakak kandung penggugat dengan tergugat (anak tiri).

Hakim tidak menetapkan semua anak di bawah asuhan penggugat. Hakim hanya menetapkan dua orang anak di bawah asuhan ibunya. Sementara dua orang anak yang lain tidak ditentukan berada di bawah asuhan ibu atau ayahnya. Pertimbangan yang digunakan hakim terkait tuntutan hak hadanah adalah: "Menimbang bahwa tentang tuntutan penggugat di mana anakanak ditetapkan di bawah asuhan penggugat dapat dikabulkan sebagian yaitu dua orang anak yang masih di bawah umur yang bernama anak kandung ketiga (9 tahun) dan anak kandung keempat (3 tahun) sampai anak-anak tersebut mumayiz, dan selainnya tidak dapat ditetapkan lagi di bawah asuhan penggugat karena mereka telah mumayiz, telah mempunyai hak untuk memilih tempat tinggalnya, ayahnya atau ibunya, hal mana sesuai dengan Pasal 105 huruf a dan b, sedangkan biaya hidup dan pendidikan anak-anak tersebut menjadi tanggungan ayah mereka atau tergugat sesuai dengan huruf c Pasal 105 Kompilasi Hukum Islam sampai anak-anak tersebut dewasa.

Penolakan hakim terhadap tuntutan penggugat terhadap dua orang anak yang lain dikarenakan telah mumayiz yaitu telah berumur 14 tahun dan 18 tahun. Oleh karenanya dapat memilih tinggal bersama ibu atau ayahnya sebagaimana yang diatur dalam Pasal 105 huruf c Kompilasi Hukum Islam. Hakim menolak tuntutan penggugat untuk menetapkan dua anak yang telah mumayiz ini di bawah asuhan penggugat. Hakim tidak menetapkan hak pilih bagi anak tersebut untuk menentukan pilihannya. Padahal secara aturan, anak yang telah berumur 12 tahun ke atas sebagaimana yang diatur dalam Kompilasi Hukum Islam dapat memilih tinggal bersama salah satu dari orang tuanya. Dengan tidak adanya pertimbangan tersebut, maka tidak adanya kepastian hukum bagi anaknya, sehingga sangatlah mungkin akan menimbulkan konflik baru untuk memperebutkan anak tersebut. 
Sementara anak yang ketiga dan keempat yang masih berumur 9 dan 3 tahun ditempatkan di bawah asuhan penggugat.

Poin ketiga amar putusan menyebutkan menetapkan dua orang anak masing-masing bernama anak kandung ketiga (perempuan) umur 9 tahun dan anak kandung keempat (perempuan) umur 3 tahun berada dalam asuhan penggugat sampai mumayiz. Dengan memperhatikan persoalan tersebut, maka tidak adanya kepastian hukum bagi anak yang sudah mumayiz yakni anak yang telah berumur 14 dan 18 tahun. Hal ini dikarenakan tidak diketahui berada di bawah asuhan ibu atau ayahnya. Tanpa adanya penetapan secara tegas dalam putusan berimplikasi pada munculnya persoalan baru untuk memperebutkan anaknya di kemudian hari. Kedua orang tua merasa berhak terhadap anak tersebut, begitu juga anak berhak menentukan pilihannya untuk tinggal bersama ibu atau ayahnya.

\section{B. Rumusan Masalah}

Berdasarkan permasalahan di atas, penelitian dibatasi pada dua fokus persoalan yaitu:

1. Bagaimana aspek kepastian hukum terhadap pemeliharaan anak mumayiz dalam Putusan Nomor 175/PDT.G/2011/MS-BNA;

2. Bagaimana perlindungan hukum bagi anak mumayiz yang belum menentukan pilihannya?

\section{Tujuan dan Kegunaan}

Tujuan yang ingin dicapai melalui kajian ini adalah untuk memahami dan menelaah serta menganalisis kepastian hukum terhadap pemeliharaan anak dalam Putusan Nomor 175/ PDT.G/2011/MS-BNA dan perlindungan hukum bagi anak yang telah mumayiz namun belum menentukan pilihannya.

Tulisan ini diharapkan memiliki beberapa kegunaan, yaitu kegunaan bagi akademis, praktisi hukum, pemerintah, dan masyarakat. Pertama, bagi akademisi, dapat memberikan sumbangsih pemikiran baru terhadap literaturliteratur yang membahas hadanah. Kedua, bagi praktisi hukum, diharapkan dapat menjadi acuan dalam menangani persoalan-persoalan hadanah pasca terjadinya perceraian orang tua. Ketiga, bagi pemerintah, diharapkan supaya dapat menjadi referensi yang baru dalam merumuskan kebijakan-kebijakan baru yang berorientasi pada perlindungan anak. Keempat, bagi masyarakat, dapat menjadi acuan sebelum menuntut hak asuh anak pasca terjadinya perceraian.

\section{Tinjauan Pustaka \\ 1. Konsep Kepastian Hukum}

Kepastian hukum merupakan salah satu dari tujuan hukum selain tujuan hukum lainnya yaitu mewujudkan keadilan dan kemanfaatan. Dari sudut pandang ilmu hukum positif normatif atau yuridis dogmatis, tujuan hukum dititikberatkan pada segi kepastian hukumnya. Dari sudut pandang filsafat hukum, tujuan hukum dititikberatkan pada segi keadilan dan dari sudut pandang sosiologi hukum, tujuan hukum dititikberatkan pada segi kemanfaatan. Sebenarnya ketiga aspek tersebut sama dengan apa yang diutarakan oleh Radbruch sebagai tiga nilai dasar hukum, yaitu keadilan, kemanfaatan, dan kepastian hukum (Rifai, 2011: 131-132).

Peraturan perundang-undangan sebagai salah satu sumber hukum memberikan jaminan kepastian hukum kepada masyarakat. Kelebihan peraturan perundang-undangan dengan norma 
lainnya yaitu tingkat prediktibilitasnya yang besar dan memberikan kepastian mengenai nilai yang dipertaruhkan. Sekali peraturan dibuat, maka menjadi pasti pulalah nilai yang hendak dilindungi oleh peraturan tersebut. Oleh karena itu tidak perlu diperdebatkan lagi apakah nilai itu bisa diterima atau tidak (Rahardjo, 2006: 84).

Kepastian hukum menginginkan hukum harus dilaksanakan dan ditegakkan secara tegas (fiat justita et pereat mundus/hukum harus ditegakkan meskipun langit akan runtuh). Kepastian hukum memberikan perlindungan kepada yustisiabel dari tindakan sewenang-wenang pihak lain dan hal ini berkaitan dalam usaha ketertiban dalam masyarakat (Rifai, 2011: 131).

Konsep kepastian hukum mengandung dua pengertian yaitu: Pertama, adanya aturan yang bersifat umum membuat individu mengetahui perbuatan apa yang boleh atau tidak boleh dilakukan. Kedua, berupa keamanan hukum bagi individu dari kesewenang-wenangan pemerintah karena dengan adanya aturan yang bersifat umum itu individu dapat mengetahui apa saja yang boleh dibebankan atau dilakukan oleh negara terhadap individu. Kepastian hukum bukan hanya berupa pasal-pasal dalam undang-undang, melainkan juga adanya konsistensi dalam putusan hakim yang satu dan putusan hakim lainnya untuk kasus serupa yang telah diputuskan (Marzuki, 2013: 137).

Peran pemerintah dan pengadilan sangat penting dalam menjaga kepastian hukum. Pemerintah tidak boleh menerbitkan aturan pelaksnaan yang tidak diatur oleh undangundang atau bertentangan dengan undangundang. Apabila hal itu terjadi, pengadilan harus menyatakan bahwa peraturan demikian batal demi hukum, artinya dianggap tidak pernah ada sehingga akibat yang terjadi karena adanya peraturan itu harus dipulihkan seperti sediakala (Marzuki, 2013: 138).

\section{Dasar Hukum Hak Memilih Bagi Anak}

Anak yang telah mencapai usia mumayiz diberikan kesempatan memilih tinggal bersama ibu atau ayahnya. Ada beberapa faktor yang mendukung sehingga seorang anak diberikan kesempatan memilih, yaitu: Pertama, anak pada usia tersebut dapat membedakan setiap tindakan yang mendatangkan kemanfaatan dan mudarat bagi dirinya. Anak dapat berpikir dalam setiap perbuatan yang akan ia lakukan. Kedua, memiliki dasar hukum yang kuat sebagaimana yang diatur dalam hukum hadis dan hukum positif yang berlaku di Indonesia. Dalam sebuah hadis di bawah ini:

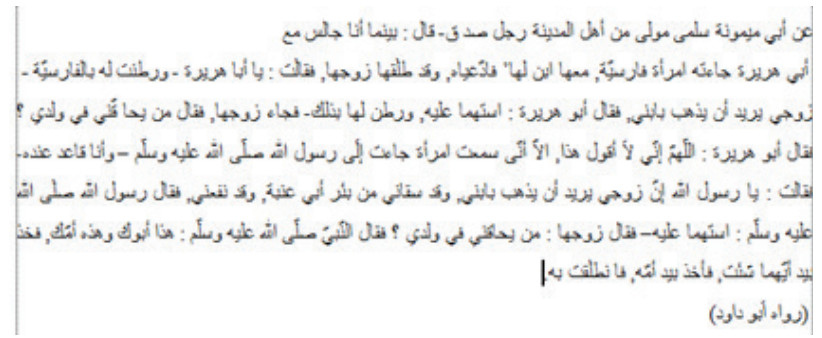

Artinya:

"Dari Abu Maimunah Sulma pelayan di kalangan Madinah dan seorang laki-laki yang jujur berkata: saat aku duduk bersama Abu Hurairah, ia didatangi seorang wanita Persia bersama anaknya, yang menjadi rebutan antara dia dan suaminya, sedangkan wanita tersebut telah ditalak suaminya. Wanita tersebut lalu bertanya kepada Abu Hurairah dengan memakai bahasa Persia, "Hai Abu Hurairah, suamiku ingin pergi bersama anakku." Abu Hurairah menjawab, "Coba kalian berdua, datangkan suamimu." Sesaat kemudian suaminya datang dan berkata, "Siapa yang mengakui lebih berhak dengan anakku?" Abu Hurairah menjawab, "Aku tidak mengatakan seperti itu, hanya saja aku pernah mendengar kisah bahwa ada seorang wanita mendatangi Rasulullah, aku saat itu duduk di dekat Nabi dan 
berkata, "Wahai Rasul, suamiku ingin pergi bersama anakku, sementara anakku telah memberiku siraman dari sumur Abi, apakah itu berpengaruh?" Rasulullah menjawab, "Coba kalian berdua datangkan suami itu." Rasulullah bersabda, "ini adalah bapamu dan ini adalah ibumu, maka peganglah tangan (salah satu dari mereka) yang kamu inginkan. " Ternyata sang anak memegang tangan ibunya dan akhirnya pergilah anak itu bersama ibunya." (H.R. Abu Daud) (Daud, 2006: 47-48).

Hadis tersebut menjelaskan tentang kebolehan seorang anak memilih tinggal bersama salah satu dari orang tuanya. Dalam konteks hadis tersebut anak memilih tinggal bersama ibunya. Meski demikian, tidak menutup kemungkinan seorang anak untuk tinggal bersama ayahnya tergantung pada kondisi dan pertimbanganpertimbangan tertentu yang dapat membawakan anak pada kondisi yang lebih baik.

Para ulama berbeda pendapat dalam memahami hadis di atas. Sebagian ulama memadukan hadis tentang hak pilih yang diberikan kepada anak dengan hadis yang menyatakan bahwa ibu lebih berhak terhadap anak. Sebagian kecil ulama berpendapat bahwa anak itu diajukan pilihan antara memilih ibu atau bapaknya. Pendapat demikian dikemukakan oleh Ishaq bin Rahawaih dengan batasan umur anak sejak tujuh tahun. Pendapat ini didasarkan pada hadis nomor dua yang memberikan kebebasan bagi anak untuk memilih tinggal bersama ibu atau bapaknya (Shan'ani, 2012: 194).

Sejak usia tujuh tahun menjelang balig Satria menyebutnya dengan istilah mumayiz. Menurutnya pada usia ini seorang anak secara sederhana telah mampu membedakan antara yang berbahaya dan yang bermanfaat bagi dirinya. Oleh karena itu, seorang anak sudah dapat menjatuhkan pilihannya yang bisa menjamin kelangsungan hidup terbaik bagi dirinya. Lebih lanjut Satria menjelaskan bahwa anak yang disebut dalam hadis di atas sudah mampu membantu ibunya mengambil air sumur, yang diperkirakan berumur di atas tujuh tahun atau sudah mumayiz. Dengan demikian, hadis tersebut menunjukkan bahwa anak yang sudah mumayiz atau sudah dianggap mampu menentukan pilihan sendiri, diberi hak untuk memilih sendiri (Zein, 2004: 171).

Ulama yang mengatakan bahwa anak tidak diberikan kebebasan untuk memilih secara tegas menyatakan: "Ibu lebih berhak mengasuh sampai anaknya bisa mandiri, apabila sudah mandiri, bapak lebih berhak mengasuh anak laki-laki dan ibu mengasuh anak perempuan." Pendapat ini dikemukakan oleh Al-Hadawaiyah dan Al-Hanafiyah. Sedangkan Malik mempunyai pandangan yang berbeda dengan ulama di atas. Malik sependapat untuk diberikan hak memilih, hanya saja ia menyatakan: "Ibu lebih berhak mengasuh anak-anak, baik laki-laki maupun perempuan."

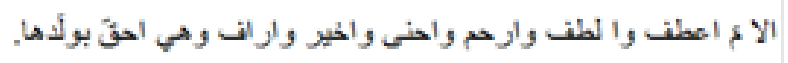

Artinya:

"Ibu lebih cenderung (kepada anak), lebih halus, lebih pemurah, lebih penyantun, lebih baik dan lebih penyayang. Ia lebih berhak terhadap anaknya. (Darajat, 1995: 159)."

Syaukani (1994: 304) dalam kitabnya Nailul Authar menyebutkan bahwa hak memilih seorang anak yang sudah mencapai usia tamyiz merupakan hal yang wajib tanpa membedakan apakah itu anak laki-laki atau anak perempuan. Lebih lanjut ia menyebutkan pengarang kitab AlBahr menceritakan dalam kitabnya, berasal dari mazhab Hadawiyah, Abu Thalib, Abu Hanifah beserta para pengikutnya dan Imam Malik 
bahwasanya tidak ada hak pemilihan, akan tetapi kapan saja anak itu sudah mampu sendiri, maka ayahlah yang paling berhak atas anak laki-laki dan ibu atas anak perempuan.

Batasan mampu (mandiri) menurut $\mathrm{Abu}$ Hanifah beserta para pengikutnya Abu Abbas dan Abu Thalib ialah anak itu sudah bisa makan dan minum serta berpakaian sendiri (Syaukani, 1994: 304).

Para ulama yang bersikukuh meniadakan hak pilih berpegang kepada sebuah hadis yang isinya: "Engkau lebih berhak atas anak itu selama belum menikah." Pendapat ini terbantah oleh kemungkinan dilakukannya penggabungan, yaitu dapat dikatakan yang dimaksud dengan "ibu lebih berhak atas anak" adalah pada usia sebelum anak disuruh memilih, bukan sesudahnya (Syaukani, 1994: 304).

Kebijakan hakim mengenai hak asuh anak yang lebih memprioritaskan kepentingan terbaik bagi anak, bukan didasarkan pada kemauan ibu atau ayah untuk mengasuhnya. Bahkan ada juga hakim yang memberikan hak pengasuh anak kepada ayah, seperti Putusan Nomor 65/PDT.G/2011/MS-BNA, Nomor 167/PDT.G/2011/MS-BNA, dan Nomor 66/ PDT.G/2012/MS-BNA (Mansari, 2013: 43). Hal ini sangat tergantung pada pertimbanganpertimbangan yang terungkap ke persidangan. Begitu juga sebaliknya, jika ibu dapat menjamin terwujudnya kehidupan anak yang lebih baik, maka anak tersebut akan diberikan kepada ibu. Sebaliknya, tidak menutup kemungkinan anak tersebut diberikan kepada ayahnya selama ayah dapat melindungi, merawat, menjaga, dan memeliharanya dengan baik.

Untuk mewujudkan hal tersebut langkah antisipasi hakim dalam memberikan hak pengasuhan anak sebenarnya menjadi penting untuk dilakukan sebagai upaya memberikan perlindungan yang dicita-citakan oleh anak. Apabila hal ini tidak dilakukan akan berakibat fatal pada masa depan anak dan masa depan bangsa ini, karena suatu saat generasi muda sekarang menjadi pemimpin pada masa yang akan mendatang.

Perlindungan hukum bagi anak mumayiz yang belum menentukan sikap/pilihan yang tidak disebutkan dalam putusan hakim keberadaan pengasuhannya di bawah asuhan ibu atau bapaknya. Perlindungan anak menjadi prioritas utama meskipun dalam putusan hanya menentukan pengasuhan anak sampai anak tersebut mumayiz. Kedua orang tua berkewajiban memeliharanya sampai anak tersebut dewasa dan dapat berdiri sendiri dan pemerintah memiliki perhatian yang serius tentang perlindungan anak.

Tujuan perlindungan anak adalah untuk menjamin terpenuhinya hak-hak anak agar dapat hidup, tumbuh, berkembang, dan berpartisipasi secara optimal sesuai dengan harkat dan martabat kemanusiaan. Serta mendapat perlindungan dari tindak kekerasan dan diskriminasi, demi terwujudnya anak Indonesia yang berkualitas, berakhlak mulia, dan sejahtera.

\section{METODE}

Tulisan ini menggunakan metode penelitian yuridis empiris. Penelitian hukum empiris (empirical law research) adalah penelitian hukum positif mengenai perilaku (behavior) anggota masyarakat dalam hubungan hidup bermasyarakat (Wijayanti \& Achmad, 2011: 97). Penggunaan metode ini dikarenakan untuk mengetahui tata cara yang dilakukan hakim dalam memberikan hak memilih bagi anak manakala usia telah mumayiz. 
Data yang digunakan dalam penelitian ini terdiri dari data sekunder yaitu bahan hukum primer dan bahan hukum sekunder. Bahan hukum primer yang digunakan yaitu Putusan Nomor 175/ PDT.G/2011/MS-BNA dan peraturan perundangundangan yang terkait dengan pembahasan. Adapun bahan-bahan sekunder berupa semua publikasi tentang hukum yang bukan merupakan dokumen-dokumen resmi. Publikasi tentang hukum meliputi buku-buku teks, jurnal-jurnal hukum, dan komentar-komentar atas putusan pengadilan (Marzuki, 2012: 181).

Pengumpulan data dilakukan dengan metode dokumentasi (documentary research) dan metode penelitian lapangan (field research). Metode dokumentasi dilakukan dengan cara menelaah sumber-sumber data sekunder yang terdiri dari bahan hukum primer, bahan hukum sekunder, dan bahan hukum tersier. Metode pengumpulan data melalui penelitian lapangan dilakukan dengan cara wawancara (Ngani, 2012: 180).

Instrumen pengumpulan data lainnya ditempuh dengan mewawancarai dua orang hakim yang mengadili dan menyelesaikan kasuskasus hak asuh anak pasca terjadinya perceraian. Analisis data dilakukan secara kualitatif setelah data-data terkumpulkan. Penelitian ini dilakukan di wilayah yurisdiksi Mahkamah Syar'iyah Banda Aceh.

\section{HASIL DAN PEMBAHASAN}

\section{A. Aspek Kepastian Hukum Pemeliharaan Anak dalam Putusan Nomor 175/ PDT.G/2011/MS-BNA}

Peranan hakim pada prinsipnya adalah melaksanakan fungsi peradilan berdasarkan peraturan perundang-undangan yang berlaku.
Dalam menjalankan tugas dan fungsi yang diembankan kepadanya, hakim harus menyadari bahwa tugasnya adalah menegakkan hukum dan memberikan putusan yang seadil-adilnya kepada masyarakat. Secara umum, dalam penyelenggaraan tugas hakim, tugas yang harus direalisasikan oleh hakim terdiri dari tiga hal, yaitu: keadilan (gerechtigheit), kemanfaatan (zwachmatigheit), dan kepastian hukum (rechtsecherheit) (Manan, 2008: 291).

Kaum idealis menyatakan bahwa tujuan hukum hadir untuk mewujudkan keadilan, sementara kaum positivis menyatakan bahwa hukum semata-mata sebagai alat untuk menciptakan ketertiban, stabilitas, dan kepastian (Sirajuddin, Fatkhurohman, \& Zulkarnain, 2015). Untuk mewujudkan ketiga hal tersebut di atas dalam suatu putusan sangatlah sulit. Kadangkalanya dalam suatu putusan hanya dapat terpenuhi aspek keadilan dan kemanfaatan, tapi tidak adanya kepastian hukum. Begitu juga sebaliknya, putusan hakim yang mencerminkan kepastian hukum, namun tidak memberikan keadilan dan kemanfaatan bagi masyarakat.

Menurut Marzuki (2013: 137), kepastian hukum bukan hanya berupa pasal-pasal dalam undang-undang, melainkan juga adanya konsistensi dalam putusan hakim yang satu dengan putusan hakim yang lain dalam putusan yang serupa. Namun pada tataran empiris di pengadilan, tidak jarang adanya perbedaan dalam memutuskan suatu perkara. Salah satu contoh dapat dilihat dalam konteks pemberian hak hadanah anak yang tidak selalu diberikan kepada ibu. Kadangkalanya hakim menetapkan ayah sebagai pengasuh bagi anak. Seperti dalam Putusan Nomor 65/PDT.G/2012/MS-BNA, di mana hakim mempertimbangkan bahwa telah adanya kesepakatan antara ayah dan ibu untuk 
memberikan hak asuh kepada ayah, maka hakim menetapkan ayah sebagai pengasuh.

\section{Putusan Nomor 167/PDT.G/2012/MS-} BNA, hakim memberikan hak pengasuhan di bawah ayah dikarenakan kedekatannya dengan anak, sedangkan Putusan Nomor 66/ PDT.G/2012/MS-BNA, hakim memberikan hak hadanah kepada ayah dikarenakan adanya kesukarelaan dari kedua belah pihak bahwa anak diasuh oleh ayah (Mansari, 2013: 61). Dengan memperhatikan ketiga putusan tersebut, maka dapatlah dikatakan bahwa hak pengasuhan tidak selamanya berada di bawah asuhan ibu, namun ada juga putusan hakim yang memberikan hak asuh kepada ayah. Sementara dalam Putusan Nomor 175/PDT.G/2011/MS-BNA, majelis hakim menetapkan ibu sebagai pengasuh dari dua orang anak sampai mumayiz. Setelah mumayiz anak tersebut dapat memilih tinggal bersama ibu maupun ayahnya sesuai dengan yang ditentukan dalam Pasal 105 huruf b Kompilasi Hukum Islam. Sedangkan dua anak lagi yang berumur 14 dan 18 tahun tidak jelas berada di bawah asuhan ibu atau ayahnya.

Diperhatikan secara saksama, amar putusan hakim yang menentukan ibu sebagai pengasuh bagi dua orang anak telah adanya kepastian hukum, karena hakim secara tegas menyatakan dalam putusannya bahwa dua orang anak tersebut berada di bawah asuhannya. Namun, aspek kepastian hukum tiada bagi anak yang telah berumur 14 dan 18 tahun. Kedua anak ini tidak dinyatakan langsung berada di bawah ibu (penggugat) dikarenakan telah mumayiz dan dapat memilih tinggal bersama ibu atau ayahnya.

Aspek kepastian hukum hanya terpenuhi bagi dua orang anak yang pertama dikarenakan hakim telah menyatakan secara tegas dalam putusan bahwa kedua anak tersebut berada di bawah asuhan ibunya. Paling tidak, terdapat tiga faktor anak tersebut diberikan kepada ibu, yaitu:

1. Ibu merupakan orang yang lebih berhak mengasuh anak sebagaimana yang terdapat dalam sebuah hadis, yaitu:

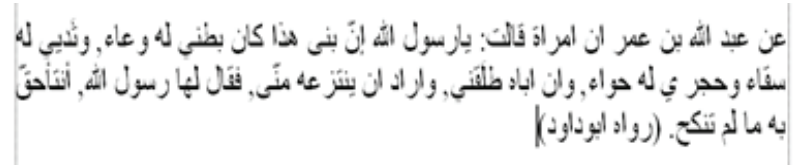

Artinya:

Dari Abdullah bin Amru: ada seorang wanita bertanya kepada Rasulullah, "Wahai Rasulullah, anakku ini dulu perutku yang mengandungnya, susuku sebagai siraman baginya, dan pengasuhan yang aku lakukan sebagai perlindungan, ayahnya sekarang telah mentalak serta ingin meminta anak ini dariku. " Rasulullah kemudian bersabda kepada sang wanita, "kamu lebih berhak atas anakmu selama kamu belum menikah." (H.R. Abu Daud) (Daud, 2006: 47).

Bahkan dalam hadis yang lain, Rasulullah mengancam orang yang memisahkan anak dari ibunya. Nabi Muhammad SAW bersabda: "Barang siapa yang memisahkan antara seorang ibu dengan anaknya, niscaya Allah akan memisahkan orang itu dengan kekasihnya di hari kiamat" (Nuruddin \& Tarigan, 2013: 212). Hadis tersebut menunjukkan bahwa anak tidak dapat dipisahkan dari ibunya. Allah akan memisahkan orang yang memisahkan anak dengan ibunya pada akhirat kelak. Ini menjadi sebuah ancaman bagi orang-orang yang tidak menaatinya.

2. Ibu memiliki sifat lemah lembut dalam mendidik dan mengasuh anak. Abu Bakar pernah mengambil sebuah kebijakan terkait perebutan anak antara Umar dengan 
seorang nenek. Pada suatu waktu setelah bercerai dengan istrinya, Umar bin Khatab pergi ke Quba dan menemui anaknya sedang bermain di depan masjid, lalu Umar mengambil anaknya dan meletakkan di atas kuda yang ia tunggangi. Kemudian datang nenek 'Ashim dan berkata "anakku," Umar pun berkata "anakku." Perebutan anak tersebut akhirnya dibawa kepada Khalifah Abu Bakar dan memutuskan anak tersebut ikut kepada ibunya dengan pertimbangan:

الا مَّ اعطف وا لطف وارحم واحنى واخير وار اف وهي احقَّ بولَّها.

Artinya:

"Ibu lebih cenderung (kepada anak), lebih halus, lebih pemurah, lebih penyantun, lebih baik, dan lebih penyayang. Ia lebih berhak terhadap anaknya." (Darajat, 1995: 159).

Hal ini sesuai dengan tujuan dari penetapan hukum Islam yaitu untuk mewujudkan kebahagiaan hidup manusia di dunia dan akhirat kelak, dengan jalan mengambil (segala) yang bermanfaat dan mencegah atau menolak yang mudarat atau yang tidak berguna bagi hidup dan kehidupan (Ali \& Heryani, 2012: 61).

3. Berdasarkan Pasal 105 huruf a Kompilasi Hukum Islam yang menentukan bahwa pemeliharaan anak yang belum mumayiz atau belum berumur 12 tahun adalah hak ibunya. Ibu lebih berhak jika seluruh syarat dan kriteria hadanah terpenuhi pada dirinya. Berbeda halnya bila ibu meninggal dunia, maka kedudukannya digantikan oleh:

a. wanita-wanita dalam garis lurus ke atas dari ibu; b. ayah;

c. wanita-wanita dalam garis lurus ke atas dari ayah;

d. saudara perempuan dari anak yang bersangkutan;

e. wanita-wanita kerabat sedarah menurut garis samping dari ibu;

f. wanita-wanita kerabat sedarah menurut garis samping ayah (Rofiq, 2015: 226).

Secara yuridis normatif, keutamaan ibu mengasuh anak secara eksplisit diatur dalam Pasal 105 Kompilasi Hukum Islam. Hakim dapat menggunakan ketentuan tersebut sebagai salah satu landasan hukum dan pertimbangannya dalam memutuskan suatu perkara. Ketentuan yang diatur dalam Kompilasi Hukum Islam menjadi salah satu acuan hakim dalam memutuskan suatu perkara yang diajukan kepadanya. Artinya, hakim dapat merujuk kepada aturan tersebut dalam menyelesaikan persoalan yang diajukan oleh para pencari keadilan (yustisiable).

Konteks positivisme hukum yang menghendaki adanya kesesuaian penerapan hukum dalam setiap putusan, Putusan Nomor 175/ PDT.G/2011/MS-BNA belum mengadopsinya dengan baik. Hal ini dikarenakan hakim belum memberikan kepastian hukum kepada empat orang anak sebagaimana yang dituntut oleh penggugat. Jika anak yang berumur 14 tahun dan 18 tahun telah mumayiz, maka perlu diperhatikan ketentuan Pasal 105 huruf b yang menentukan pemeliharaan anak yang sudah mumayiz diserahkan kepada anak untuk memilih di antara ayah atau ibunya sebagai pemegang hak pemeliharaannya. 
Ketentuan tersebut menjadi petunjuk bahwa hakim dalam memutuskan perkara yang diajukan kepadanya, anak perlu dimintakan pendapatnya untuk memilih tinggal bersama ibu atau ayahnya. Namun, dalam putusan tersebut seolah-olah hakim mengabaikan kedua orang anak yang telah mumayiz. Padahal penggugat (ibu) dalam petitum gugatannya telah meminta kepada hakim supaya empat orang anak tersebut berada di bawah pengasuhannya. Poin ketiga petitum gugatan menyatakan menetapkan penggugat sebagai pengasuh terhadap empat orang anak yang namanya tersebut di atas. Dalam pandangan positvism hukum, kepastian hukum menjadi karakteristik paling fundamental.

Aliran ini berpandangan bahwa hukum yang seharusnya adalah hukum yang terdapat dalam peraturan tertulis bukan pada kaidah yang tidak tertulis (moral). Segala putusan yang diputuskan oleh hakim harus merujuk pada ketentuan yang berdaulat yang dibentuk oleh pihak yang memiliki otoritatif. Dalam dunia peradilan, pengaruh pandangan positivisme hukum melahirkan aliran legisme, di mana hakim hanya dipandang sebagai terompet undang-undang, atau sebagai "bo uche de la loi" (Ali \& Heryani, 2012: 39-40).

Montesquieu pernah mengemukakan bahwa "hakim-hakim rakyat tidak lain hanya corong yang mengucapkan teks undang-undang. Jika teks itu tidak berjiwa dan tidak manusiawi, para hakim tidak boleh mengubahnya, baik tentang kekuatannya maupun tentang ketaatannya." (Ali \& Heryani, 2012: 40).

Justianus (Ali \& Heryani, 2012: 41) mengancam dengan pidana bagi yang memberanikan diri menafsirkan undang-undang. Menurutnya, interpretasi merupakan suatu hal yang salah (perversio). Interpretasi hanya dapat dipergunakan jika sudah mendapatkan persetujuan dari kaisar. Hal ini mengindikasikan bahwa patokan utama bagi paham positivisme adalah adanya kepastian hukum sebagaimana yang telah ditetapkan oleh pihak yang berwenang. Selain aturan yang telah ditetapkan tidak dapat digunakan oleh hakim di pengadilan.

Pandangan demikian cenderung kaku dan hanya berorientasi pada aturan hukum tertulis semata tanpa memperhatikan nilai-nilai yang hidup dan berkembang dalam masyarakat. Belum tentu aturan hukum tertulis dapat memberikan keadilan dan kemanfaatan kepada pencari keadilan. Hakim yang mengadili dan menyelesaikan perkara merupakan suatu langkah menerapkan aturan-aturan hukum kepada setiap kasus yang terjadi. Hakim tidak dapat dipaksakan menerapkan aturan hukum tertulis tanpa mempertimbangkan keadilan dan kemanfaatan (Ali \& Heryani, 2012: 203).

Keberadaan hakim di pengadilan bertujuan menegakkan kebenaran dan keadilan serta selalu menjunjung tinggi hukum (Wijayanta \& Firmansyah, 2011: 42). Untuk mewujudkan keadilan dan kebenaran tidak hanya berpatokan pada aturan hukum tertulis, namun perlu diperhatikan pula kebiasaan dan keadilan bagi masyarakat. Ini menjadi kewajiban hakim untuk memperhatikannya, karena hakim memiliki tanggung jawab besar merealisasikannya. Siregar dalam Azizy (2004: 217) pernah mengatakan undang-undang secara jelas menegaskan tanggung jawab hakim itu bukan kepada negara, bukan kepada bangsa, tetapi pertama kepada Tuhan Yang Maha Esa baru kepada dirinya. Kalau inilah landasan tanggung jawab hakim akankah ia ragu-ragu menguji, kalau perlu membatalkan peraturan yang bertentangan dengan Pancasila dan Tuhan Yang Maha Esa. 
Hakikatnya tugas pokok hakim adalah menerima, memeriksa, mengadili, memutuskan dan menyelesaikan setiap perkara yang diajukan kepadanya. Tugas hakim secara konkrit dalam memeriksa dan mengadili suatu perkara melalui tiga tindakan, yaitu: Pertama, mengkonstatir yakni menetapkan atau merumuskan peristiwa konkrit. Kedua, mengkualifisir yaitu menetapkan atau merumuskan peristiwa hukumnya. Ketiga, mengkonstituir, yaitu menetapkan hukumnya dan memberikan keadilan kepada para pihak (Sutiyoso, 2006: 17)

Setiap putusan yang diputuskan oleh hakim memiliki tiga kekuatan yang melekat padanya, yaitu:

1. Kekuatan mengikat. Artinya putusan tersebut dapat mengikat para pihak yang terlibat dalam perkara tersebut. Putusan yang telah memiliki kekuatan hukum tetap tidak dapat diganggu gugat dan harus dipatuhi serta ditaati oleh mereka yang terlibat di dalamnya. Putusan Nomor 175/ PDT.G/2011/MS-BNA merupakan putusan yang memiliki kekuatan hukum bagi para pihak yaitu penggugat (ibu) dan tergugat (ayah). Keduanya harus menjalankan amar putusan tersebut sebagaimana mestinya. Jika putusan itu masih membuka peluang bagi kedua belah pihak untuk mendapatkan anak tersebut, maka keduanya memiliki hak untuk itu. Begitu juga anak berhak menentukan pilihannya. Persoalan ini dapat saja muncul jika adanya keinginan salah satu pihak mempersoalkannya kembali hak hadanah. Sebaliknya, persoalan tidak akan muncul jika ibu maupun ayah memiliki kesepakatan bersama untuk menempatkan anak di bawah asuhan salah satu pihak.
Pasal 156 huruf c Kompilasi Hukum Islam menentukan apabila pemegang hadanah ternyata tidak dapat menjamin keselamatan jasmani dan rohani anak, meskipun biaya telah dicukupi, maka atas permintaan kerabat yang bersangkutan memindahkan hak hadanah kepada kerabat lain yang mempunyai hak hadanah pula. Selanjutnya Pasal 156 huruf e Kompilasi Hukum Islam memberikan kesempatan kepada para pihak yang berkepentingan terhadap hadanah untuk membawa kasus ke pengadilan agama supaya mendapatkan penyelesaiannya. Dalam ketentuan tersebut ditentukan bahwa bilamana terjadi perselisihan mengenai hadanah dan nafkah anak, pengadilan agama memberikan putusannya berdasarkan huruf a, b, c, dan d.

Perselisihan mengenai pemeliharaan ini besar kemungkinan terjadi. Apalagi peluang untuk mendapatkannya sudah diberikan oleh ketentuan hukum yang berlaku. Untuk menentukan pilihannya, seorang anak perlu mengajukan persoalannya ke pengadilan supaya ditetapkan calon pengasuh bagi dirinya. Namun sangat sulit dilakukan oleh anak sendiri pada usianya yang relatif masih muda, di mana ia tidak dapat melakukan perbuatan hukum. Anakanak pada usia 12 sampai dengan 18 tahun perlu mendapatkan pendampingan dari pihak lain dalam melakukan setiap perbuatan hukum. Meskipun dalam putusan hakim menentukan salah satu orang tua memelihara anak, bukan berarti pihak lain tidak dapat memelihara dan mendidiknya. Seorang ayah di samping berkewajiban memberikan segala yang dibutuhkan dalam menunjang pertumbuhan 
dan pendidikannya, dapat pula memelihara anak meskipun dalam kondisi berjauhan dari dirinya.

Kewajiban memelihara anak menjadi tanggung jawab bersama pasangan suami istri. Istri berkewajiban dalam bentuk memelihara dan merawatnya sementara dalam bidang materi menjadi tanggung jawab ayahnya. Jika ayah tidak mampu membayar biaya hidup kepada anak, ibu dapat pula dibebankan tanggung jawab memberikan nafkah kepada anak. Keharusan membayar biaya nafkah biasanya diputuskan oleh hakim.

2. Kekuatan pembuktian. Kegunaan dari sebuah putusan adalah dapat dijadikan sebagai bahan bukti jika suatu saat diperdebatkan kembali terhadap suatu persoalan hukum yang dihadapi oleh para pihak. Putusan dapat dijadikan alat bukti yang sangat kuat dan dasar bagi salah satu pihak jika timbul lagi permasalahan di kemudian hari. Jika dianalisis dalam konteks Putusan Nomor 175/PDT.G/2011/ MS-BNA, maka diktum amar putusan menjadi bukti konkret yang menunjukkan bahwa anak yang tidak ditegaskan dalam putusan dapat dimintakan kembali untuk ditempatkan di bawah asuhan ibu atau ayahnya.

3. Kekuatan eksekutorial, artinya setiap putusan yang telah memiliki kekuatan hukum tetap dapat dilakukan eksekusi jika salah satu pihak tidak melaksanakannya.

Dapat disimpulkan bahwa Putusan Nomor 175/PDT.G/2011/MS-BNA hanya mencerminkan kepastian hukum bagi anak yang telah berumur 9 dan 8 tahun (anak ketiga dan keempat). Sementara anak yang berumur 14 dan 18 tahun tidak ada kepastian bagi mereka berdua berada di bawah asuhan ibu atau ayahnya. Untuk mengantisipasi supaya menjamin adanya kepastian hukum kepada masyarakat, maka dalam merumuskan suatu putusan, hakim harus memuat secara jelas dan tegas dalam diktum putusannya. Jika anak yang telah mumayiz diberikan pilihan untuk memilih tinggal bersama ibu atau ayahnya, maka hakim perlu memberikan hak pilih baginya. Hal ini harus diperhatikan supaya tidak terjadinya persoalan di kemudian hari.

Diktum amar putusan itu menjadi salah satu kekuatan pembuktian bagi para pihak bila muncul persoalan di kemudian hari. Menurut Mertokusumo(1979: 19), putusan hakim memiliki tiga kekuatan, yaitu: kekuatan mengikat, kekuatan pembuktian, dan kekuatan eksekutorial. Kekuatan pembuktian berarti bahwa putusan tersebut dapat dijadikan sebagai bukti konkret untuk mengakhiri konflik dan pertikaian yang berkepanjangan di antara para pihak. Oleh karena itu, Manan (2008: 296) menyarankan supaya dalam setiap putusan, hakim harus memperhatikan beberapa hal berikut, yaitu: harus bersifat tegas dan lugas, terperinci dan jelas maksudnya, memperhatikan sifat dari putusan yang akan dijatuhkan, apakah konstitutif, deklaratif atau condemnatoir dan ditulis secara ringkas, padat, dan terang.

\section{B. Perlindungan Hukum bagi Anak yang Belum Menentukan Pilihannya}

Konsekuensi yang muncul pasca terjadinya perceraian orang tua adalah memelihara anakanak yang lahir dari perkawinan. Kedua orang tua berkewajiban memeliharanya sampai anak dapat mandiri terhadap kehidupannya. Pasal 41 Undang-Undang Nomor 1 Tahun 1974 
menentukan bahwa akibat putusnya perkawinan karena perceraian adalah:

1. Baik ibu atau bapak tetap berkewajiban memelihara dan mendidik anak-anaknya, semata-mata berdasarkan kepentingan anak, bilamana ada perselisihan mengenai penguasaan anak-anak, pengadilan memberi keputusannya.

2. Bapak yang bertanggung jawab atas semua biaya pemeliharaan dan pendidikan yang diperlukan anak-anak itu; bilamana bapak dalam kenyataan tidak dapat memberi kewajiban tersebut, pengadilan dapat menentukan bahwa ibu ikut memikul biaya tersebut.

3. Pengadilan dapat mewajibkan kepada mantan suami untuk memberikan biaya penghidupan dan atau menentukan suatu kewajiban bagi bekas istri.

Pemeliharaan anak merupakan kewajiban yang menjadi tanggung jawab kedua orang tuanya. Kewajiban tersebut terus berlanjut meskipun hubungan perkawinan antara orang tuanya berakhir. Anak wajib dipelihara, dilindungi, dan diberikan perlindungan dari halhal yang membahayakan bagi dirinya sampai dewasa. Orang yang berhak memelihara anak pasca perceraian adalah ibunya. Dalam Pasal 105 huruf a Kompilasi Hukum Islam menyatakan bahwa ibu merupakan orang yang lebih berhak mengasuh anak. Ibu lebih berhak jika memenuhi kriteria seorang pengasuh.

Terdapat sejumlah kriteria yang harus dimiliki oleh calon pengasuh yaitu: berakal dan dewasa, bertanggung jawab (amanah) memiliki kemampuan dalam melakukan tugas hadanah, pengasuh harus bersih diri dari penyakit kronis dan penyakit menahun, dan kesamaan agama antara pengasuh dengan mahdhün (anak yang dipelihara) (Yanggo, 2010: 256).

Sejumlah kualifikasi yang telah disebutkan di atas harus dimiliki oleh seorang pengasuh. Hal ini bertujuan untuk mewujudkan kepentingan terbaik bagi anak (the best interest of child). Masa depan anak sangat ditentukan oleh pengasuh yang akan mendidik dan memeliharanya. Seorang anak yang diasuh oleh pengasuh yang tidak memiliki tanggung jawab dan amanah akan berimplikasi pada pertumbuhan anak pada masa yang akan datang. Anak akan mengalami berbagai persoalan di kemudian hari. Anak yang telah mumayiz dapat memilih tinggal bersama ibu atau ayahnya.

Putusan Nomor 175/PDT.G/2011/MSBNA tidak menyebutkan secara jelas hak asuh anak yang telah mumayiz berada di bawah asuhan salah satu dari orang tuanya. Dalam putusan hanya menyebutkan anak kandung kedua (perempuan) berumur 9 tahun dan anak kandung ketiga (perempuan) berumur 3 tahun berada di bawah asuhan penggugat sampai mumayiz. Sementara hak asuh anak yang telah berumur 14 dan 18 tahun dapat dipertanyakan keberadaannya.

Hak asuh anak yang telah mumayiz tidak adanya kepastian. Sehingga kedua orang tua dapat memperebutkan kembali hak asuh tersebut. Karena kedua-duanya memiliki hak yang sama terhadap anak tersebut. Pasal 41 huruf a UndangUndang Nomor 1 Tahun 1974 tentang Perkawinan menyatakan bahwa akibat putusnya perkawinan karena perceraian ialah baik ibu atau bapak tetap berkewajiban memelihara dan mendidik anakanaknya, semata-mata berdasarkan kepentingan anak; bilamana ada perselisihan mengenai penguasaan anak-anak, pengadilan memberi keputusannya. 
Ketentuan tersebut memberikan hak yang sama kepada kedua orang tua untuk memelihara dan mendidik anaknya hingga dewasa. Jika terjadi perselisihan dan perebutan mengenai penguasaan anak, maka pengadilan dapat memberikan keputusan terhadap persoalan tersebut. Permohonan mendapatkan anak kembali dapat meminta kepada pengadilan supaya ditetapkan di bawah asuhannya.

Pasal 86 ayat (1) Undang-Undang Nomor 7 Tahun 1989 tentang Pengadilan Agama menyatakan gugatan soal penguasaan anak, nafkah anak, nafkah istri, dan harta bersama suami istri dapat diajukan bersama-sama dengan gugatan perceraian ataupun sesudah putusan perceraian memperoleh kekuatan hukum tetap. Dengan demikian baik ayah maupun ibu memiliki legal standing yang sangat kuat untuk memohonkan kembali kepada pengadilan agama atau mahkamah syar'iah supaya anak berada di bawah asuhannya. Secara de jure memang kedua orang tua memiliki landasan hukum dalam rangka menuntut anaknya, akan tetapi kekuasaan menetapkan anak tersebut berada di bawah asuhan ibu atau ayahnya berada pada palu hakim. Hakim yang akan menentukan layak atau tidaknya seseorang ditetapkan sebagai pengasuh anak.

Pemberian hak pengasuhan kepada ibu atau ayah dilatarbelakangi oleh dua alasan, yaitu: Pertama, apabila salah seorang di antara ibu atau ayah memperebutkan hak asuh anak yang telah berumur 14 dan 18 tahun. Apabila di antara mereka tidak ada yang memperebutkan kembali hak pengasuhan pasca mumayiz, anak tersebut akan masih tetap berada di bawah asuhan ibunya (Khairil, Hakim Mahkamah Syar'iyah Banda Aceh, wawancara, 2016). Karena dalam hukum acara perdata hakim bersifat pasif.
Menurut Asikin (2015: 10), hakim dalam memeriksa perkara perdata bersifat pasif, dalam arti kata bahwa ruang lingkup atau luas pokok sengketa yang diajukan kepada hakim untuk diperiksa pada asasnya ditentukan oleh para pihak yang beperkara dan hakim. Hakim hanya membantu para pencari keadilan dan berusaha mengatasi serta menyelesaikan setiap perkara yang diajukan kepadanya.

Kedua, adanya pihak yang menuntut kembali hak pengasuhan supaya diberikan kepadanya. Wujud dari keinginan para pihak ini menunjukkan keseriusan salah satu pihak dalam mengasuh dan merawat anak bila ditempatkan di bawah asuhannya (Samsul Bahri, Hakim Mahkamah Syar'iyah Banda Aceh, wawancara, 2016).

Permohonan dari seorang ayah menjadi alasan paling utama bagi hakim memberikan hak asuh kepadanya. Tanpa adanya permohonan darinya, anak tersebut tetap menjadi kewajiban bersama, merawat, memelihara, mengasuh, dan mendidiknya meskipun anak tersebut berada di bawah asuhan ibu. Jika kedua orang tua tidak memperebutkan hak asuh yang telah mumayiz, maka konsekuensi yang muncul adalah kedua orang tua berkewajiban memeliharanya, meskipun keberadaan anak berada pada salah satu pihak. Dengan kata lain, meskipun dalam amar Putusan Nomor 175/PDT.G/2011/MS-BNA, hakim tidak menetapkan secara tegas hak pemeliharaan anak, namun kewajiban memeliharanya tetap berjalan hingga anak tersebut dewasa dan mandiri. Perlindungan hukum bagi dirinya harus diupayakan dalam rangka mewujudkan kemaslahatan dan kepentingan terbaik bagi dirinya.

Kedua orang tua memiliki kewajiban yang sama seperti sebelum terjadinya perceraian. 
Orang tua berkewajiban memberikan kasih sayang kepadanya meskipun kehidupan antara orang tuanya berpisah (Tektona, 2012: 22). Selain itu, anak berhak menentukan dengan siapa dia akan tinggal. Jika anak memilih tinggal bersama ibunya juga boleh, begitu juga sebaliknya jika anak tinggal bersama ayahnya. Orang tua berkewajiban memberikan pendidikan kepada anak sampai ia dewasa. Karena pendidikan merupakan hak yang harus diberikan oleh orang tua kepada anaknya, baik pendidikan dunia maupun akhirat. Kewajiban lainnya adalah memperhatikan kesehatan anak dan tempat tinggal yang layak baginya.

Semua itu bertujuan untuk merealisasikan hak-hak yang seharusnya diperoleh anak. Perlindungan terhadap hak-haknya harus dikedepankan meskipun dalam putusan hakim tidak menentukan siapa yang berhak mengasuh pasca anak mencapai usia mumayiz. Menurut Waluyadi (2009: 1), perlindungan hukum bagi anak dapat diartikan sebagai upaya perlindungan hukum terhadap berbagai kebebasan dan hak asasi anak (foundamental rights and freedoms of children) serta berbagai kepentingan yang berhubungan dengan kesejahteraan anak. Jadi masalah perlindungan hukum bagi anak mencakup lingkup yang sangat luas.

Dalam memutuskan suatu perkara yang diajukan kepadanya, hakim memiliki independensinya sendiri atau kekuasaan negara yang merdeka untuk menyelenggarakan peradilan guna menegakkan hukum dan keadilan berdasarkan Pancasila (Kamil, 2012: 9). Namun hakim akan sangat hati-hati dalam memutuskan suatu perkara. Begitu juga dengan perkaraperkara yang berkaitan dengan anak, hakim akan mempertimbangkan berbagai aspek yang mendatangkan kemanfaatan baginya. Hakim dalam memberikan hak pengasuhan anak tidak dilakukan secara serta merta, akan tetapi memiliki mekanisme tertentu yang harus dilalui. Mekanisme yang dimaksudkan di sini merupakan serangkaian tahapan-tahapan pemeriksaan perkara di persidangan pada umumnya. Secara garis besar prosedur pemeriksaan perkara di persidangan terdiri dari tahapan berikut ini:

1. Sidang pertama, pemeriksaan identitas para pihak dan upaya perdamaian.

2. Sidang kedua, pembacaan gugatan atau permohonan.

3. Sidang ketiga, jawaban tergugat.

4. Sidang keempat, replik penggugat.

5. Sidang keenam, duplik tergugat.

6. Sidang ketujuh, pembuktian.

7. Sidang kedelapan, kesimpulan.

8. Sidang kesembilan, pembacaan putusan (Mujahidin, 2008: 161).

Mekanisme pemeriksaan perkara di persidangan sebagai yang telah disebutkan di atas bertujuan untuk mengetahui fakta-fakta konkret yang terungkap dalam persidangan. Seperti adanya hubungan hukum antara penggugat dengan tergugat atau antara pemohon dengan termohon, adanya suatu sengketa dalam perkara yang diajukan, dan lain sebagainya. Dari berbagai tahapan tersebut, tahapan pembuktian menjadi tahap yang sangat penting dan menentukan baik atau tidaknya nasib masa depan anak.

Pada saat pembuktian, hakim akan menilai bukti-bukti dan saksi-saksi yang diajukan ke persidangan. Melalui informasi-informasi yang disampaikan oleh saksi setelah disumpah 
oleh majelis hakim. Informasi tersebut akan dipertimbangkan dan dirumuskan dalam pertimbangan hukum hakim yang dicantumkan dalam putusan. Keterangan tersebut akan diseleksi dan disesuaikan antara saksi yang satu dengan saksi yang lain supaya tidak terjadi disparitas informasi yang disampaikan terhadap kedekatan antara orang tua atau anak atau informasi-informasi lainnya yang diterangkan oleh saksi (Samsul Bahri, Hakim Mahkamah Syar'iyah Banda Aceh, wawancara, 2016).

Untuk mengantisipasi supaya tidak terjadi hal-hal yang tidak diinginkan oleh anak bila ditempatkan di bawah asuhan ibu atau ayahnya, hakim memiliki cara tersendiri dalam rangka memberikan kepentingan terbaik bagi anak. Hakim akan mengundang anak tersebut ke persidangan untuk dimintai keterangannya mengenai kedekatan secara psikologis antara anak dan orang tuanya. Upaya ini dilakukan supaya anak dapat menentukan pilihannya secara baik dan hakim akan menilai keterangan yang disampaikan oleh anak (Khairil, Hakim Mahkamah Syar'iyah Banda Aceh, wawancara, 2016).

Tindakan yang dilakukan hakim tersebut kalau diperhatikan sangat sesuai dengan tiga aliran dalam ilmu hukum manakala merumuskan suatu putusan, yaitu: Pertama, aliran etis, yang menganggap bahwa pada prinsipnya tujuan hukum itu semata-mata hanya untuk mencapai keadilan. Kedua, aliran utilities, yang menganggap bahwa pada prinsipnya, tujuan hukum itu hanyalah untuk menciptakan kemanfaatan atau kebahagiaan masyarakat. Ketiga, aliran normative yuridis, yang menganggap bahwa pada prinsipnya tujuan hukum itu adalah untuk menciptakan kepastian hukum (Rifai, 2011: 129-130).
Menurut Khairil, ketiga hal tersebut sangat sulit diwujudkan dalam suatu putusan terhadap suatu kasus tertentu. Karena adanya keadilan belum tentu terpenuhi kepastian hukum, dan tercapai kepastian hukum belum tentu dapat memberikan nilai kemanfaatan yang lebih besar kepada anak. Prioritas yang paling utama adalah memberikan kebahagiaan yang sebesar-besarnya kepada anak, meskipun tidak tercapainya kepastian hukum. Jika hal ini sudah terpenuhi, meskipun tidak adanya kepastian hukum bukanlah persoalan bagi hakim dalam memutuskan perkara. Itulah salah satu kriteria dari putusan hakim yang sangat profesional. Menurut Sarwono (2014: 138), kriteria putusan hakim yang profesional yaitu mencerminkan keadilan, tidak adanya perlawanan dari pihak yang kalah, tidak dibatalkan oleh putusan hakim yang lebih tinggi, dan pelaksanaan putusannya tidak mengalami hambatan.

Kebijakan hakim mengenai hak asuh anak di Mahkamah Syar'iyah Banda Aceh lebih memprioritaskan kepentingan terbaik bagi anak, bukan didasarkan pada kemauan ibu atau ayah untuk mengasuhnya. Jika ibu dapat menjamin terwujudnya kehidupan anak yang lebih baik, maka anak tersebut akan diberikan kepada ibu. Sebaliknya, tidak menutup kemungkinan anak tersebut diberikan kepada ayahnya selama ayah dapat melindungi, merawat, menjaga, dan memeliharanya dengan baik (Samsul Bahri, Hakim Mahkamah Syar'iyah Banda Aceh, wawancara, 2016).

Langkah antisipasi hakim dalam memberikan hak pengasuhan anak sebenarnya menjadi penting untuk dilakukan sebagai upaya memberikan perlindungan yang dicita-citakan oleh anak. Apabila hal ini tidak dilakukan akan berakibat fatal pada masa depan anak dan masa 
depan bangsa ini, karena suatu saat generasi muda sekarang menjadi pemimpin pada masa yang akan datang. Dalam memberikan hak asuh anak kepada ibu atau ayah kiranya perlu belajar pada contoh kasus yang terjadi pada cerita di bawah ini:

Dalam sebuah riwayat Ibnu Qayyim, bahwa dua orang tua yaitu ayah dan ibu bersengketa mengenai anaknya di hadapan hakim. Lalu anak itu disuruh memilih di antara kedua orang tuanya dan ternyata anak tersebut memilih ayahnya. Ibunya memprotes, katanya: "Tanyakanlah, mengapa dia memilih ayahnya." Kemudian hakim menanyakan kepada anak tersebut. Setelah ditanya, anak menjawab "setiap hari ibuku mengirimkanku kepada seorang penulisan seorang ahli fikih, di mana keduanya memukulku. Sedangkan ayah, membiarkanku bermain bersama anakanak yang lain/berdasarkan jawaban anak tersebut, hakim memutuskan si anak tinggal bersama ibunya" (Syaukani, 1994: 306).

Berdasarkan riwayat tersebut, inti penting dari pengasuhan anak adalah terwujudnya kehidupan dan masa depan anak menjadi lebih baik. Bukan pada siapa yang akan mengasuhnya. Baik ibu maupun bapak memiliki kesempatan yang sama untuk mengasuh anak sepanjang dapat merawat dan mendidiknya dengan baik. Hakim telah memperhatikan nilai-nilai yang bermanfaat bagi anak dalam menentukan hak pengasuhan bagi salah satu dari kedua orang tuanya.

Para ulama sepakat bahwa yang didahulukan dalam pengasuhan tersebut adalah ibu dan ayahnya, sekaligus tidak ada kerusakan. Apabila ada kerusakan salah satu pasangan, maka yang lain menjadi lebih utama tanpa diragukan lagi. Syariat tidak bertujuan mendahulukan satu di antara yang lain sekadar karena hubungan kerabat. Akan tetapi, syariat mendahulukan pihak yang lebih utama, lebih mampu, dan lebih baik. Dengan demikian, apabila penggugat maupun tergugat memiliki sifat tidak baik, maka yang lebih berhak didahulukan adalah yang lebih baik dari keduanya (Abdurrahman, 2007: 65-66).

\section{KESIMPULAN}

Diktum amar Putusan Nomor 175/ PDT.G/2011/MS-BN yang menyatakan menetapkan dua orang anak masing-masing bernama anak kandung ketiga (perempuan) umur 9 tahun dan anak kandung keempat (perempuan) umur 3 tahun berada dalam asuhan penggugat sampai mumayiz hanya mencerminkan kepastian hukum bagi kedua anak tersebut dan tidak mencerminkan aspek kepastian hukum bagi anak yang telah mumayiz. Hal ini dikarenakan hakim menolak mengabulkan hak hadanah anak yang telah berumur 14 dan 18 tahun yang dituntut oleh penggugat dikarenakan telah mumayiz. Sehingga kedua anak ini tidak jelas berada di bawah pengasuhan ibu atau ayahnya hingga dewasa. Akibatnya membuka peluang terjadinya konflik yang berkepanjangan antara kedua orang tua untuk memperebutkannya kembali anak tersebut.

Perlindungan hukum bagi anak yang telah mumayiz yang belum menentukan sikap/pilihan terhadap salah satu dari kedua orang tuanya menjadi kewajiban bersama untuk mengasuh dan memeliharanya. Namun jika anak telah menentukan pilihan, maka orang yang dipilih itulah yang menjaga dan merawatnya hingga dewasa sementara ayah adalah orang yang berkewajiban menafkahi dan membiayai segala kebutuhan sesuai dengan kemampuannya.

\section{SARAN}

Hakim harus hati-hati dalam memutuskan perkara anak supaya tidak merugikan bagi diri dan masa depannya serta berakibat pada hilangnya hak-hak yang seharusnya ia dapatkan. 
Hakim harus selalu memprioritaskan kepentingan terbaik bagi anak (the best interest of the child) daripada status ibu ataupun ayah, karena jenis kelamin belum menjamin terwujudnya kebaikan dan mendatangkan manfaat bagi dirinya.

Dalam memeriksa perkara hak asuh anak, hakim harus menanyakan langsung kepada anak ingin tinggal bersama ibu atau ayahnya.

\section{DAFTAR ACUAN}

Abdurrahman, A. (2007). Asy-Syarh al-Bulughū alMaram. Jilid VI. Jakarta: Pustaka Azzam.

Ali, A., \& Heryani, W. (2012). Menjelajahi kajian empiris terhadap hukum. Jakarta: Kencana Prenada Media Group.

. (2012). Sosiologi hukum kajian empiris terhadap pengadilan. Cetakan 1. Jakarta: Kencana Prenada Media Group.

Asikin, Z. (2015). Hukum acara perdata di Indonesia. Cetakan 1. Jakarta: Prenada Media Group.

Azizy, Q. (2004). Elektisisme hukum nasional kompetisi antara hukum Islam \& hukum umum. Yogyakarta: Gama Media.

Darajat, Z. (1995). Ilmu figh. Cetakan 1. Yogyakarta: Dana Bhakti Wakaf.

Daud, A. (2006). Sunan Abu Daud. Jilid 2, Cetakan 1. Al-Albani, M. N. (Ed.). Jakarta: Pustaka Azzam.

Ghozali, A. R. (2010). Fiqh munakahat. Jakarta: Kencana Prenada Media Group.

Kamil, A. (2012). Filsafat kebebasan hakim. Jakarta: Kencana.
Manan, A. (2008). Penerapan hukum acara perdata di lingkungan peradilan agama. Cetakan 5. Jakarta: Kencana Prenada Media Group.

Mansari. (2013). Pemberian hak hadhanah kepada ayah (Analisis Putusan Hakim Mahkamah Syar'iyah Banda Aceh). Skripsi. Banda Aceh: Fakultas Syariah dan Ekonomi Islam IAIN ArRaniry Banda Aceh.

Marzuki, P. M. (2012). Penelitian hukum. Cetakan 9. Jakarta: Prenada Media Group. . (2013). Pengantar ilmu hukum. Cetakan 5. Jakarta: Prenada Media Group.

Mertokusumo, S. (1979). Hukum acara perdata Indonesia. Yogyakarta: Liberty.

Mujahidin, A. (2008). Pembaharuan hukum acara perdata peradilan agama \& mahkamah syar'iyah di Indonesia. Cetakan 1. Jakarta: Ikatan Hakim Indonesia (IKAHI).

Ngani, N. (2012). Metodologi penelitian \& penulisan hukum. Yogyakarta: Pustaka Yustisia.

Nuruddin, A., \& Tarigan, A. A. (2013). Hukum perdata Islam di Indonesia studi kritis perkembangan hukum Islam dari fikih, UU No. 1/1974 sampai KHI. Cetakan 4. Jakarta: Kencana Prenada Media Group.

Rahardjo, S. (2006). Ilmu hukum. Bandung: Citra Aditya Bakti.

Rifai, A. (2011). Penemuan hukum oleh hakim dalam perspektif hukum progresif. Cetakan II. Jakarta: Sinar Grafika.

Rofiq, A. (2015). Hukum perdata Islam Indonesia. Ed. Revisi, Cetakan 2. Jakarta: Rajawali Pers.

Sarwono. (2004). Hukum acara perdata teori \& praktik. Jakarta: Sinar Grafika.

Shan'ani, M. I. A. (2012). Subulussalām asy-Syarh al- 
Bulūghul Marām. Jilid III, Cetakan 6. Darwis, A. N. M (Ed.). Jakarta: Darus Sunnah Press.

Sirajuddin, Fatkhurohman, \& Zulkarnain. (2015). Legislative drafting pelembagaan metode partisipatif dalam pembentukan peraturan perundang-undangan. Malang: Setara Press.

Sutiyoso, B. (2006). Metode penemuan hukum upaya mewujudkan hukum yang pasti \& berkeadilan. Yogyakarta: UII Press.

Syarifuddin, A. (2014). Hukum perkawinan Islam di Indonesia antara fiqh munakahat \& UndangUndang Perkawinan. Cetakan 5. Jakarta: Prenada Media.

Syaukani, M. (1994). Nailū al-Authar asy-Syarh alMuntaqa al-Akhbar min al-Hadits as-Sayyid al-Akhya. Jilid VII. Musthafa, A. B. (Ed.). Semarang: CV. asy-Syifa.

Tektona, R. I. (2012, Juli). Kepastian hukum terhadap perlindungan hak anak korban perceraian. Muwâzâh, 4(1), 21-29.

Waluyadi. (2009). Hukum perlindungan anak. Cetakan 1. Bandung: Mandar Maju.

Wijayanta, T., \& Firmansyah, H. (2011, Februari). Perbedaan pendapat dalam putusan Pengadilan Negeri Yogyakarta \& Pengadilan Negeri Sleman. Jurnal Mimbar Hukum, 23(1), 38-60.

Wijayanti, A., \& Achmad, L. S. (2011). Strategi penulisan hukum. Bandung: Lubuk Agung.

Yanggo, H. T. (2010). Fikih perempuan kontemporer. Jakarta: Ghalia Indonesia.

Zein, S. E. M. (2004). Problematika hukum keluarga Islam kontemporer analisis yurisprudensi dengan pendekatan ushuliyah. Jakarta: Prenada Media. 